\title{
Bioinspired Hydrogel Surfaces to Augment Corneal Endothelial Cell Monolayer Formation
}

Fatma Zehra Erkoc-Biradli ${ }^{\text {*** }}$

Alp Ozgun ${ }^{* *}$

M.Özgen Öztürk-Öncel ${ }^{1}$

Merve Marcali ${ }^{2}$

Caglar Elbuken ${ }^{2,5}$

Osman Bulut ${ }^{3}$

Rifat Rasier ${ }^{4}$

Bora Garipcan $^{1 *}$

bora.garipcan@boun.edu.tr

1. Institute of Biomedical Engineering, Bogazici University, Istanbul, Turkey

2. UNAM-National Nanotechnology Research Center, Institute of Materials Science and Nanotechnology, Bilkent University, Ankara, Turkey

3. Civil Engineering Faculty, Istanbul Technical University, Istanbul, Turkey

1 Department of Ophthalmology, Demiroglu Bilim University, Istanbul, Turkey

5. Faculty of Biochemistry and Molecular Medicine, Faculty of Medicine, University of Oulu, 90014 Oulu, Finland.

**Authors have equal contribution

* Corresponding Author

This article has been accepted for publication and undergone full peer review but has not been through the copyediting, typesetting, pagination and proofreading process, which may lead to differences between this version and the Version of Record. Please cite this article as doi: 10.1002/term.3173.

This article is protected by copyright. All rights reserved. 


\begin{abstract}
Corneal endothelial cells (CECs) have limited proliferation ability leading to corneal endothelium (CE) dysfunction and eventually vision loss when cell number decreases below a critical level. Although transplantation is the main treatment method, donor shortage problem is a major bottleneck. The transplantation of in vitro developed endothelial cells with desirable density is a promising idea. Designing cell substrates that mimic the native $\mathrm{CE}$ microenvironment is a substantial step to achieve this goal. In the presented study, we prepared polyacrylamide (PA) cell substrates that have a microfabricated topography inspired by the dimensions of CECs. Hydrogel surfaces were prepared via two different designs with small and large patterns. Small patterned hydrogels have physiologically relevant hexagon densities $\left(\sim 2000\right.$ hexagons $\left./ \mathrm{mm}^{2}\right)$, whereas large patterned hydrogels have sparsely populated hexagons $\left(\sim 400\right.$ hexagons $\left./ \mathrm{mm}^{2}\right)$. These substrates have similar elastic modulus of native Descemet's membrane (DM) ( 50 kPa) and were modified with Collagen IV (Col IV) to have biochemical content similar to native DM. The behaviour of bovine corneal endothelial cells (BCECs) on these substrates was investigated and results show that cell proliferation on small patterned substrates was significantly $(p=0.0004)$ higher than the large patterned substrates. Small patterned substrates enabled a more densely populated cell monolayer compared to other groups ( $\mathrm{p}=0.001$ vs. flat and $\mathrm{p}<0.0001$ vs. large patterned substrates). These results suggest that generating bioinspired surface topographies augments the formation of $\mathrm{CE}$ monolayers with the desired cell density, addressing the in vitro development of CE layers.
\end{abstract}

Keywords: Bioinspiration, Bovine corneal endothelial cells, Corneal endothelium, Corneal regeneration, Polyacrylamide, Substrate topography.

This article is protected by copyright. All rights reserved. 


\section{Introduction}

Cornea has five histologically different layers; corneal endothelium (CE) is the innermost layer of cornea, located at the basement membrane, which is named Descemet's membrane (DM). CE consists of mostly hexagonally shaped corneal endothelial cells (CECs) monolayer and has a crucial function in sustaining corneal transparency via controlling corneal hydration (Joyce, 2003). CECs have high metabolic activity, but they do not proliferate in vivo. For this reason, CECs decrease in number with aging and become larger to make up for the lost space. It is known that human CEC density is around 4000 cell $/ \mathrm{mm}^{2}$ in new-borns, this number decreases to nearly 2000 cell $/ \mathrm{mm}^{2}$ in elders (Bartakova, Kunzevitzky, \& Goldberg, 2014). CE can maintain corneal transparency unless the endothelial cell density falls below a critical level that is generally 400-500 cells $/ \mathrm{mm}^{2}$ (Joyce, 2012). In addition to aging, there are several reasons, such as high intraocular pressure, surgical trauma and endothelial dystrophies that can cause CEC loss and result in blindness in severe cases (Bourne, 2003; Zavala, Ló Pez Jaime, Barrientos, \& Valdez-Garcia, 2013).

The main treatment of the vision loss related to loss of CE is transplantation, which is also called keratoplasty (Tan, Dart, Holland, \& Kinoshita, 2012). There are some major challenges such as donor shortage, immune rejection, and complications, related with such surgical procedures. A great number of approaches such as cell therapy, using stem cells, artificial or bioengineered corneas have been utilised to address these issues (Bartakova et al., 2014). However, high density and functional CECs are needed for all these studies. Biomimetic and bioinspiration approaches have offered promising solutions to many tissue-engineering problems like in CE. From a tissue engineering point of view, designing cell substrates that mimic cells' in vivo microenvironment is essential. Extracellular matrix (ECM), which provides chemical and structural support to cells, is the ideal biological material to mimic since it has a role in a diverse range of processes such as differentiation, migration, survival and homeostasis of the cell (Theocharis, Skandalis, Gialeli, \& Karamanos, 2016). Furthermore, cells respond to mechanical properties (Discher, Janmey, \& Wang, 2005) and topographical cues of substrates and direct their behaviours accordingly (Bettinger, Langer, \& Borenstein, 2009). Biomimetic and bioinspiration

This article is protected by copyright. All rights reserved. 
approaches in tissue engineering studies can be summarized as tuning up substrate stiffness in line with the target tissue (Engler, Sen, Sweeney, \& Discher, 2006), duplicating target ECM structure by functionalizing substrate surface with related ECM proteins or small oligopeptide sequences (Chen \& Hunt, 2007) and emulating topographical features of target tissue (Wang \& L., 2011). These approaches were utilised for many tissues such as bone, cardiovascular, neural (Shin, Jo, \& Mikos, 2003) or corneal tissue (Palchesko, Lathrop, Funderburgh, \& Feinberg, 2015).

When it comes to bioinspired approaches for the recovery of corneal endothelium, obtaining transplantable CEC sheets by bioengineered cell substrates is the ultimate goal for prospective therapeutic applications (Lai, Chen, \& Hsiue, 2007). It is known that DM, which is in direct contact with CECs, has an elastic modulus value of 50.0 $\pm 17.8 \mathrm{kPa}$ (Last, Liliensiek, Nealey, \& Murphy, 2009) and includes Collagen type IV and VIII fibrils (Eghrari, Riazuddin, \& Gottsch, 2015). Several studies were performed with the aim of obtaining functional CE monolayers. A study showed that Col IV coated PDMS substrates that have elastic modulus of $50 \mathrm{kPa}$ result in monolayer formation with higher CEC densities and exhibit more native-like polygonal morphology among other experimental groups (Palchesko et al., 2015). Another study, concludes that micro and nanotopography of cell substrates combined with ECM coatings promotes the formation of tight junctions at cell interfaces and exhibit improved $\mathrm{CE}$ phenotype (Koo, Muhammad, Peh, Mehta, \& Yim, 2014). A recent study presents that DM microtopography can promote the differentiation of human mesenchymal stem cell into corneal endothelial-like cells (Gutermuth et al., 2019). Although the hexagonal monolayer formation of CECs is well-known and hexagonal shape factor was used as a criterion for successful in vitro CE development (Palchesko et al., 2015), an indirect approach has been taken to create functional CE monolayer (Gutermuth et al., 2019). There has not been a study that dictates the hexagonal microtopography (with varying cell-to-cell distances) and a biomimetic chemical surface modification, simultaneously. Additionally, to address the high number of transplantation patients, there is need for a more standard mechanical design and chemical surface modification of cell substrate for the ex vivo CEC monolayer formation.

In this study, we develop a comprehensive and effective bioinspired CE formation approach by combining similar mechanical and chemical properties of DM including the hexagonal 
morphology of the CECs as topographical features on substrates. We have prepared polyacrylamide (PA) hydrogel surfaces with CECs-dimensions inspired topography. PA substrates have been utilised in mechanotransduction studies (Stanton, Tong, \& Yang, 2019) including cornea tissue engineering (Molladavoodi, Kwon, Medley, \& Gorbet, 2015). In our study, PA hydrogels were preferred since they are easily handled and finely tuneable at such low elastic moduli and they can successfully replicate patterns of the mold. The elastic moduli of hydrogel substrates $(32.87 \pm 5.35 \mathrm{kPa})$ have been adjusted as comparable with the underlying DM layer stiffness. Hydrogel surfaces were prepared via two different designs having small and large patterns. Small patterned hydrogels have physiologically relevant hexagon densities $(\sim 2000$ hexagons $/ \mathrm{mm}^{2}$ ) and large patterned hydrogels have sparsely populated hexagons ( 400 hexagons $/ \mathrm{mm}^{2}$ ). These bioinspired hydrogel surfaces have been modified with Col IV, which is an essential component of the extracellular matrix of these cells. Our results show that positioning cells with optimal distances from each other through surface topography augments the formation of CE monolayers with the desired cell density.

\section{Materials and Methods}

\subsection{Fabrication of Silicon Wafer Molds}

PA substrates with two different patterns were prepared using standard soft lithography (Xia \& Whitesides, 1998). The shape, depth and dimensions of the hexagonal pattern on the silicon wafer were prepared by inspiration from the natural corneal endothelial cell microenvironment (Zavala et al., 2013). Patterns with about $4 \mu \mathrm{m}$ height were fabricated on a silicon wafer using photolithography. In both patterns, negative SU-8 2005 photoresist (MicroChem) was used. In the first step, SU-8 2005 photoresist was spun on a silicon wafer as an adhesive layer at $2500 \mathrm{rpm}$ for $40 \mathrm{~s}$ and was exposed to $120 \mathrm{~mJ} / \mathrm{cm}^{2}$. Then, the second layer of the SU-8 2005 photoresist was spun on the base layer at $3000 \mathrm{rpm}$ at for $40 \mathrm{~s}$ and was exposed to $100 \mathrm{~mJ} / \mathrm{cm}^{2}$ through a mask. After exposure, the wafer was post baked at $65^{\circ} \mathrm{C}, 95^{\circ} \mathrm{C}$ and, $65^{\circ} \mathrm{C}$ for $1 \mathrm{~min}, 3 \mathrm{~min}$ and 1 min, respectively. In the final step, these master molds were cleaned with nitrogen for the preparation of PA substrates. Designs and optical microscope images of silicon wafer molds are provided in Supporting Information (Figure S1).

This article is protected by copyright. All rights reserved. 


\subsection{Preparation of Polyacrylamide Hydrogels}

A gel recipe which was adapted from (Heras-Bautista et al., 2014) used for the polymerization of PA hydrogels. Briefly, stock solutions of acrylamide (AA) $40 \%$ (w/v) in phosphate buffer saline (PBS) and 2\% w/v N, N'-Methylenebisacrylamide (Bisacrylamide) in deionized water were prepared. Tetramethylethylenediamine (TEMED) (1:10 diluted) and 200 $\mathrm{mM}$ Ammonium persulfate (APS) solutions were used for the polymerization. Our final working solution contains $15 \%$ AA monomer and $0.3 \%$ Bisacrylamide cross-linker. GelBond® PAG films (Lonza Rockland) were utilised for the preparation of thin hydrogel substrates. $40 \mu \mathrm{L}$ of prepolymer solution was dropped onto petri dish and activated side of sterilized film was placed on top of this droplet. Gel solution covers the whole hydrophilic surface of the film and gel polymerization was initiated. After completion of polymerization, the polymerized gel attached film was separated from the petri dish. These non-patterned gels were named as flat PA hydrogels.

To synthesize bioinspired PA hydrogels, hexagonal structure of human corneal endothelial cells was formed onto silicon wafer using photolithography. This structure was transferred to PA surfaces via soft lithography. Hexagonally patterned bioinspired PA hydrogels were synthesized in a similar way to flat hydrogels. This time, $40 \mu \mathrm{L}$ of pre-polymer solution was dropped onto the pattern of silicon wafer, then sterilized GelBond ${ }^{\circledR}$ PAG film was put on top of this droplet. After one-hour, polymerized gel attached films were carefully removed from the silicon wafer mold (Erkoc, 2017). These hydrogels were named as bioinspired small and large patterned PA hydrogels.

\subsection{Modification of PA Hydrogels}

Flat and patterned PA hydrogels were modified with Col IV via Sulfosuccinimidyl 6 (40azido -20-nitrophenylamino) Hexanoate (Sulfo-SANPAH). Sulfo-SANPAH solution (0.2 $\mathrm{mg} / \mathrm{mL}$ ) was poured onto each hydrogel and gel surfaces were exposed to UV light (at around 10 $\mathrm{cm}$ distance) about 30 minutes. After washing with deionized (DI) water, $100 \mu \mathrm{g} / \mathrm{mL}$ Col IV solution (in $0.1 \mathrm{M}$ acetic acid) was pipetted onto gels and these hydrogels were kept at $+4{ }^{\circ} \mathrm{C}$ 
overnight. Afterwards, Col IV solution was removed, and gels were washed several times with DI water (Aratyn-Schaus, Oakes, Stricker, Winter, \& Gardel, 2010).

\subsection{Dynamic Mechanical Analysis}

The mechanical characterization of the cylindrical specimens $(n=4)$ was performed by a dynamic mechanical analyzer (DMA TA Instruments Q800) at room temperature in compression mode. To obtain the stress-strain diagram, the DMA controlled force module was selected with $0.2 \mathrm{~N} / \mathrm{min}$ force increment steps up to $2 \mathrm{~N}$. The measurement tool of the instrument applying the preloading at $0.001 \mathrm{~N}$ determined the thickness of each specimen, which varies around $1.6 \mathrm{~mm}$. The sample diameters were measured around $20 \mathrm{~mm}$ by a micrometer before loading the samples.

\subsection{Confirmation of Collagen IV Immobilization on PA Hydrogels}

\subsubsection{Water Contact Angle Measurements}

In order to confirm the Col IV modification, water contact angle values of uncoated and Col IV coated hydrogels were measured $(n=4)(C A M ~ 100, K S V)$ using $3 \mu 1$ DI water dropped on the hydrogel surface followed by 15 seconds long imaging with one second intervals.

\subsubsection{Gel Immunostaining}

Two groups of hydrogel samples were prepared for gel immunostaining experiments. First group was modified with Col IV using the heterobifunctional linker Sulfo-SANPAH, whereas only Col IV was added on the second group. Anti-Collagen IV antibody (ab6586) (1:100) as a primary antibody and Donkey Anti-Rabbit IgG H\&L (Alexa Fluor® 555) (Ab150062) (1:300) as a secondary antibody were used for hydrogel immunostaining. Blocking was performed in $1 \%$ BSA and $22.52 \mathrm{mg} / \mathrm{mL}$ glycine in PBS containing 0.1\% Tween-20 (PBST) for one hour before adding primary antibody solution. Primary antibody solution was diluted 1:100 in 1\% BSA in PBST and added onto each gel for overnight incubation at $4{ }^{\circ} \mathrm{C}$. After aspiration of excess antibody, gels were washed with PBS three times for $5 \mathrm{~min}$ in each. Then 1:300 diluted secondary antibody was added to each gel and incubated for $1 \mathrm{~h}$ at room temperature in dark. Gels were washed with PBS three times in dark and fluorescence microscopy images were taken

This article is protected by copyright. All rights reserved. 
(Leica, DM IL). Ten different images were taken from each group for quantification with Image $\mathrm{J}$.

\subsection{Cell Culture on PA substrates}

Bovine corneal endothelial cells (BCECs), BCE C/D-1b (ATCC ${ }^{\circledR}$ CRL-2048 ${ }^{\mathrm{TM}}$ ) were used for the cell culture studies to investigate the behaviour of BCECs on PA hydrogels. All PA hydrogels that were used for cell culture were produced in aseptic conditions. Prior to synthesis, all solutions were filtered through $0.2 \mu \mathrm{m}$ syringe filters and further steps were performed under sterile conditions in laminar flow hood. Hydrogel samples were modified with sterile Col IV solution and they were incubated in cell growth medium at least two hours before cell seeding. DMEM High Glucose (4.5 g/l), with L-Glutamine and Sodium Pyruvate (Biosera) was used as a culture medium. The medium also contained 10\% v/v Fetal Bovine Serum (FBS, Merck) and 1\% v/v penicillin/streptomycin (Biosera). $2 \times 10^{4}$ cells were seeded in each well on 48 well-plates and maintained at $37{ }^{\circ} \mathrm{C}, 5 \% \mathrm{CO}_{2}$. Cell cultures studies were carried out on flat and bioinspired small/large patterned surfaces with and without Col IV coating. Cell viability on these substrates was measured with the 3-[4,5-dimethylthiazol-2-yl]-2,5-diphenyltetrazolium bromide (MTT) assay on the $1^{\text {st }}$ and $7^{\text {th }}$ day of the culture.

\subsubsection{Immunofluorescence Staining}

Cell samples were fixed with $4 \%$ paraformaldehyde solution on $7^{\text {th }}$ day of culture. $0.1 \%$ Triton-X 100 was utilised for permeabilization, then blocking was performed in $1 \%$ bovine serum albumin (BSA) in phosphate buffer saline (PBS) for 20 min. $6.6 \mu \mathrm{m}$ phalloidin-Alexa Fluor 488 conjugate methanolic stock solution was diluted in PBS (1:40) and added onto cells. After incubating for $20 \mathrm{~min}$, cells were washed with PBS twice for $5 \mathrm{~min}$ in each. DAPI counterstaining was performed by incubating cells in DAPI staining solution (300 nM) for $3 \mathrm{~min}$. After washing with PBS, images were taken with blue and violet excitation filters for Alexa Fluor 488 and DAPI, respectively.

To observe the expression of $\mathrm{Na}^{+} / \mathrm{K}^{+}$ATPase, cell samples were fixed in $4 \%$ paraformaldehyde solution for $10 \mathrm{~min}$ at $7^{\text {th }}$ day of culture, after twice washing with PBS permeabilized in $0.1 \%$ Triton-X 100 solution for $10 \mathrm{~min}$. They were washed with PBS three times

This article is protected by copyright. All rights reserved. 
then blocked in $1 \%$ bovine serum albumin (BSA) and $22.52 \mathrm{mg} / \mathrm{mL}$ glycine in PBST for $30 \mathrm{~min}$. $\mathrm{Na}^{+} / \mathrm{K}^{+}$ATPase was labelled with 1:100 diluted anti-sodium potassium ATPase antibody [EP1845Y] ab76020 (Abcam) overnight at $4{ }^{\circ} \mathrm{C}$. The following day, primary antibody solution was decanted, and samples were washed with PBS three times for $5 \mathrm{~min}$ in each wash and incubated with 1:300 diluted (in PBST) secondary antibody, Alexa Fluor® 488 conjugated Goat Anti-Rabbit IgG H\&L Ab 150077 (Abcam), and counterstained with DAPI.

To observe the expression of other functional marker N-cadherin, cell culture period was extended to 21 days. Other group cell samples were fixed with $4 \%$ paraformaldehyde solution on $21^{\text {st }}$ day of the culture. N-Cadherin was labelled with 1:100 diluted (in PBST) N-Cadherin antibody ab18203 (Abcam) and 1:300 diluted (in PBST) Alexa Fluor® 488 conjugated Goat Anti-Rabbit IgG H\&L Ab 150077 (Abcam) via same procedure as mentioned above.

\subsubsection{Western Blot Analysis}

The expression of $\mathrm{Na}^{+} / \mathrm{K}^{+}$ATPase on TCP and Col IV coated flat, small patterned and large patterned PA substrates was examined via Western Blot analysis. Whole cell proteins were extracted into 2X Laemmli buffer. These protein lysates were loaded to 4-10\% PA gel. Protein bands were resolved at $200 \mathrm{~V}$ (Bio-Rad, Mini Protean) and transferred to PVDF membranes (Bio-Rad, Transblot Turbo). Blocking was performed for one hour in 5\% non-fat milk in Tris$\mathrm{HCl}$ buffered saline (TBS) containing 0.1\% Tween-20 (TBST). Membranes were washed with PBST three times, then incubated with Rabbit Anti-Sodium Potassium ATPase [EP1845Y] ab76020 (1:1000, Abcam) primary antibody in 2\% BSA in TBST overnight at $4^{\circ} \mathrm{C}$. The following day, membranes were washed with PBST three times, $5 \mathrm{~min}$ in each. They were incubated with Horseradish peroxidase conjugated secondary antibody (1:1000, ab6721 Abcam) with 2\% BSA in TBST for $1 \mathrm{~h}$ at room temperature. Then membranes were washed with TBST and bands were visualized using 3,3',5,5'-tetramethylbenzsidine (TMB) based substrate (Thermofisher).

\subsection{Statistical Analysis}

Graphpad Prism software was utilised for the statistical analysis. All results were demonstrated as mean \pm standard deviation. The difference between the two experimental groups

This article is protected by copyright. All rights reserved. 
was examined using t test. Tukey's post-hoc analysis of two-way ANOVA test for grouped sample analysis was utilised after ordinary one-way ANOVA test. $\mathrm{p}<0.05$ was regarded as statistically significant and stated as $*$ for $\mathrm{p}<0.05$, ** for $\mathrm{p}<0.01, * * *$ for $\mathrm{p}<0.001$ and $* * * *$ for $\mathrm{p}<0.0001$.

\section{Results}

\subsection{Preparation and Characterization of Polyacrylamide Hydrogels}

PA hydrogels were polymerized on the silicon wafer master molds. Size and spacing of individual hexagons are dictated by the mold designs (Figure 1-A). Hexagonal shapes of wells were also visible in both patterns without disruptions. However, a slight shrinkage (app. 16\% reduction in diameter) was observed in both hexagonal patterns after hydrogels are synthesized. No creasing or other irregularities were present on flat substrate surfaces. Mechanical analysis of these hydrogels was performed to confirm a mean elastic modulus comparable to $50.0 \pm 17.8 \mathrm{kPa}$, the elastic modulus of native DM. Stress-strain curve was provided in Figure 1-B and mean elastic moduli were calculated as $32.87 \pm 5.35 \mathrm{kPa}$ and $36.12 \pm 10.99 \mathrm{kPa}$ for uncoated flat PA, Col IV coated hydrogels, respectively. Further investigation on the effect of surface topography on mechanical strength of the substrates was performed. Samples from each experimental group (flat, small patterned and large patterned PA substrates and their Col IV coated forms) were examined and there was no statistically significant difference between experimental groups $(\mathrm{p}=0.374)$ in their elastic moduli values. Elastic moduli values and sample stress-strain curves were provided in Supporting Information (Figure S2 and S3). Upon Col IV coating of surfaces through Sulfo-SANPAH method, an increase in water contact angle was observed as shown in Figure 1-C. Water contact angles were measured as $33.41 \pm 3.96^{\circ}$ for uncoated PA hydrogels and $101.51 \pm 4.99^{\circ}$ for Col IV coated PA hydrogels. Covalent immobilization of Col IV was further verified by incubating with Sulfo-SANPAH treated hydrogels in Col IV solution and immunostaining for Col IV. Fluorescence signal was 20 -fold higher $(p<0.0001)$ in SulfoSANPAH treated group compared to untreated group (Figure 1-D and 1-E).

On day 7, the difference in cell morphology and the number of attached cells were discernible for BCECs seeded on uncoated and Col IV coated substrates. Very few cells were attached on uncoated surfaces and they displayed rounded morphology. Some cells were visible inside large patterned substrate dips, but they do not otherwise interact with the patterns. Col IV

This article is protected by copyright. All rights reserved. 
coated substrates were populated with cells that are attached and spread flat on the surface as shown in Figure 2.

The samples were evaluated for cell proliferation using MTT assay as an indicator of total cell number on day 1 and day 7 as given in Figure 3. When these time points were compared, there was no significant increase in flat $(\mathrm{p}=0.799)$ and large patterned $(\mathrm{p}=0.990)$ substrates according to time effect Tukey's post-hoc analysis of two-way ANOVA test. On the other hand, small patterned surfaces showed a $37 \%$ increase $(\mathrm{p}=0.009)$ in mean absorbance. Two-way ANOVA analysis of pattern effect revealed significant difference between all groups namely, $\mathrm{p}=0.022$ for flat vs. small patterned, $\mathrm{p}=0.031$ for flat vs. large patterned and $\mathrm{p}=0.0004$ for small patterned vs. large patterned substrates.

F-actin staining revealed uninterrupted fiber networks in tissue culture plate (TCP) and small patterned groups on day 7 while large patterned and flat groups displayed continuous actin fibers only within individual cell clusters (Figure 4). Nuclei in TCP group and flat substrates are distributed randomly whereas they are evenly spaced as individuals trapped in hexagonal wells on small patterned substrates. Each of the dips in large patterned substrates contains multiple nuclei and results in an uneven cell distribution.

On the $7^{\text {th }}$ day of culture, cells in all experimental groups were positive for functional CE marker $\mathrm{Na}^{+} / \mathrm{K}^{+}$ATPase and no difference were observed in the signal patterns (Figure 5-A). Moreover, when probed by western blot, the total levels of $\mathrm{Na}^{+} / \mathrm{K}^{+}$ATPase were similar $(\mathrm{p}=0.376)$ between groups (Figure 5-B). However, when cell densities were examined on different groups, small patterned substrates were significantly more densely populated compared to other PA substrates ( $p<0.0001$ vs. large patterned and $p<0.001$ vs. flat substrate). There were $1500 \pm 342$ cells $/ \mathrm{mm}^{2}$ on small patterned substrates while the cell densities on flat and large patterned substrates were $985 \pm 230$ cells $/ \mathrm{mm}^{2}$ and $740 \pm 160$ cells $/ \mathrm{mm}^{2}$, respectively. Mean cell density of the TCP group was $1692 \pm 425$ cells $/ \mathrm{mm}^{2}$ and did not statistically differ from small patterned substrates $(\mathrm{p}=0.389)$ (Figure 5-C).

Immunostaining of N-cadherin (Figure 6-A) showed that the continuous signal in TCP group became confined to clusters when cells were cultured on flat or large patterned PA surfaces for 21 days. Conversely, $\mathrm{N}$-cadherin immunoreactivity was restored to a great extent on small patterned substrates. Moreover, when cell densities were analysed on different groups (Figure 6-

This article is protected by copyright. All rights reserved. 
B), small patterned substrates were significantly more densely populated compared to other PA substrates ( $\mathrm{p}=0.001$ vs. flat and $\mathrm{p}<0.0001$ vs. large patterned substrates). There were $2990 \pm 504$ cells $/ \mathrm{mm}^{2}$ on small patterned substrates while the cell densities on flat and large patterned substrates were $1460 \pm 680 / \mathrm{mm}^{2}$ and $800 \pm 290 / \mathrm{mm}^{2}$, respectively. Mean cell density of the TCP group was $2530 \pm 940 / \mathrm{mm}^{2}$ and did not statistically differ from small patterned substrates $(\mathrm{p}=0.561)$. Cell density was significantly higher on small patterned hydrogels than flat (nonpatterned $)(p=0.001)$ and large patterned hydrogels $(\mathrm{p}<0.0001)$ both at $7^{\text {th }}$ and $21^{\text {st }}$ day of culture.

\section{Discussion}

The literature about corneal endothelial engineering emphasizes retention of functional cell markers and establishing the natural barrier formation of corneal endothelium through tightly packed cells in a continuous monolayer. Chemical and mechanical in vitro cues required to achieve these goals were previously optimized. Palchesko et al. showed that PDMS cell substrates that have $50 \mathrm{kPa}$ elastic modulus and Col IV coating boost cell proliferation. In addition, compared to other ECM proteins, Col IV coating on the substrates results in tightly packed cells reminiscent of natural corneal endothelial structure (Palchesko et al., 2015). Recently, Gutermuth et al. demonstrated that microtopography that mimics DM could direct human mesenchymal stem cells (hMSCs) to differentiate into corneal endothelial like cells (Gutermuth et al., 2019). Also in an another study, micro- and nanotopography effects on CEC behaviour was investigated by using various patterns such as channels, gratings, round pillars and wells with different sizes (Teo, Goh, Ng, Koo, \& Yim, 2012). Patterns of different geometry and size together with several ECM protein coatings were used to modulate the proliferation, morphometry, and phenotype of CECs (Koo et al., 2014). In our study, we aimed to advance these approaches by adding a topographical dimension through patterns that are inspired by the hexagonal shapes of CECs in vivo (Bourne, 2003),(Zavala et al., 2013) and combining all mechanical, topographical and chemical cues to obtain substrates more similar to the natural environment of endothelium.

In the presented study, hexagonally shaped well patterns were created on PA substrates. Micro-well patterned topography was chosen by the inspiration from the microtopography of native DM (Gutermuth et al., 2019). Densely populated ( 2000 pillars $/ \mathrm{mm}^{2}$ ) small hexagonal

This article is protected by copyright. All rights reserved. 
pillars were fabricated on molds to match physiologically relevant cell densities while large pillar patterns were used to represent sparsely populated ( 400 pillars $/ \mathrm{mm}^{2}$ ) cell densities (Zavala et al., 2013). We show that these pillars were successfully replicated as hexagonal wells on PA hydrogel surfaces. In addition to bioinspired topography, our hydrogel substrates have also comparable stiffness and biochemical content of DM. The elastic modulus of DM was determined as $50.0 \pm 17.8 \mathrm{kPa}$, within the $20-80 \mathrm{kPa}$ range reported previously (Last et al., 2009). PA hydrogel preparation protocol was optimized to match this elastic modulus value. However, due to the inertness of uncoated PA, very few adhered BCECs were observed under microscope, after cell seeding. ECM protein modification of PA before cell culture studies is known to promote cell adhesion (Beningo, Lo, \& Wang, 2002; Kandow, Georges, Janmey, \& Beningo, 2007). In our study, Col IV was chosen as a coating material since DM contains substantial amount Col IV fibrils (Eghrari et al., 2015). Surfaces of PA hydrogels were successfully decorated with Col IV as evidenced by immunostaining of covalently bound Col IV as well as the dramatically increased water contact angle values. WCA of uncoated PA hydrogels was $33.41 \pm 3.96^{\circ}$, after Col IV modification, WCA was determined as $101.51 \pm 4.99^{\circ}$. The increase in WCA was in accordance with the literature (Lanniel et al., 2011). This increase was expected as Col IV molecules passivize the extremely hydrophilic surface groups of PA and alter the surface chemistry.

Cell viability and proliferation were evaluated by MTT assay on Day 1 and Day 7 after cell seeding (Day 0). Interestingly, two-way ANOVA test showed that the effect of small patterns on cell proliferation was highly significant vs. large patterns $(\mathrm{p}=0.0004)$, significant vs. flat hydrogels $(\mathrm{p}<0.05)$ and cells on small patterned substrates grew more efficiently. When compared to the literature, the effect of substrate topography on cell proliferation varies with the shape and size of topographical features, cell type, substrate material and chemical coatings (Wang \& L., 2011; Xiong, Gao, Qin, Jia, \& Ren, 2019). For instance, in the study that conducted with BCECs, round pillar topography led to higher proliferation rate when compare the other patterns (Teo et al., 2012). Another study indicated that the increase of pillar diameter (from 20 $\mu \mathrm{m}$ to $40 \mu \mathrm{m}$ ) and height (from $10 \mu \mathrm{m}$ to $20 \mu \mathrm{m}$ ) decreased the ability of the continuous cell monolayer formation of primary HCECs (Rizwan et al., 2016). The effect on cell proliferation observed with our bioinspired topography (micro-well patterned topography) could be attributed to total substrate area being used more efficiently due to even spacing of individual cells and

This article is protected by copyright. All rights reserved. 
preventing formation of overcrowded and under populated areas. Furthermore, small patterned substrates enabled a more densely populated cell monolayer compared to other groups due to cells being forced to interact from equal distances and anchored nuclei positions.

Actin cytoskeleton organization of BCECs and distribution of cell nuclei were revealed more clearly upon fluorescent staining. Small patterned hydrogels trapped individual nuclei inside the wells leading to almost uniform spacing and a tremendous increase in surface coverage by CECs. Large patterned wells accommodated multiple nuclei which resulted in uneven distribution of Factin fibers and uncovered areas similar to flat substrates.

An important marker of $\mathrm{CE}$ function is the activity of $\mathrm{Na}^{+} / \mathrm{K}^{+}$ATPase pumps, which regulates hydration of cornea (Bonanno, 2012). The presence of $\mathrm{Na}^{+} / \mathrm{K}^{+}$ATPase activity was confirmed via immunofluorescence staining. All experimental groups in our study yielded similar $\mathrm{Na}^{+} / \mathrm{K}^{+}$ ATPase levels indicating that substrate elasticity or surface topography has no discernible effect on the activity of $\mathrm{Na}^{+} / \mathrm{K}^{+}$ATPase pumps at $7^{\text {th }}$ day of culture. Total $\mathrm{Na}^{+} / \mathrm{K}^{+}$ATPase levels on small patterned substrates were higher in some isolated Western blot experiments. However, replicated measurements did not present a statistically significant $\mathrm{Na}^{+} / \mathrm{K}^{+}$ATPase activity difference on small patterned substrate $(\mathrm{p}=0.157)$. When compared to the literature, BCECs on PDMS substrates with nanopillar surface topography express the highest $\mathrm{Na}^{+} / \mathrm{K}^{+}$ATPase immunofluorescence signals (Teo et al., 2012), in another study, primary HCECs on mechanically improved gelatine methacrylate (GelMA) substrates with square-array of $1 \mu \mathrm{m}$ pillars with $6 \mu \mathrm{m}$ spacing and hexagonal-array of $1 \mu \mathrm{m}$ pillars with $6 \mu \mathrm{m}$ spacing have higher $\mathrm{Na}^{+} / \mathrm{K}^{+}$ATPase expression compared to unpatterned substrates (Rizwan et al., 2017). The reason for our result may be that $7^{\text {th }}$ day is an early period for the expression of $\mathrm{Na}^{+} / \mathrm{K}^{+}$ATPase. In another study, cell culture period was more than 14 days to allow cells for expressing functional markers (Choi et al., 2010). Therefore, cell culture period was extended to observe the expression of other functional marker $\mathrm{N}$-cadherin.

$\mathrm{N}$-cadherin is an important player in cell-cell interactions as it facilitates adhesion and signalling between cells (Derycke \& Bracke, 2004). Accumulation of N-cadherin at plasma membrane interfaces between cells could be observed on ex-vivo CE samples when imaged with confocal microscopy. Being an important cell junction marker in CE engineering, N-cadherin's presence is an indicator of cell monolayer integrity (Vassilev, Mandai, Yonemura, \& Takeichi,

This article is protected by copyright. All rights reserved. 
2012). In this study, expression of N-cadherin was investigated in the extended culture period, as it needs higher cell densities to form cell junctions (Peh et al., 2013). When cell-cell interactions were probed by immunostaining of N-cadherin, small patterned substrates and TCP group displayed a homogenous signal across cell monolayer while no interaction was observed between cell clusters formed on flat substrates. Interestingly, even though large patterned substrates allowed cytosol and F-actin fibers to surpass walls of individual wells, N-cadherin was largely confined inside the wells, indicating lack of cell-cell interactions between wells and cell monolayer integrity. Since small-patterned hydrogels have patterns that is both small and closer to each other, increased cell-cell interaction resulted in enhanced N-Cadherin expression. Proper positioning of cells and cell-cell communications end up cell behaviour that more similar to corneal endothelial phenotype.

Cell density is regarded as a crucial parameter for the assessment of human donor corneas when postoperative cell loss is also considered (Borderie et al., 1998). Therefore, in vitro development of endothelial cells with specified density constitutes one of the main objectives of endothelium regeneration strategies. Cell densities were examined on different groups at $7^{\text {th }}$ and $21^{\text {st }}$ day of culture; a similar trend in cell density results was observed for both short-term and long-term culture period. Small patterned substrates were significantly more densely populated compared to other PA substrates. The results show that more similar topography to native DM resulted in the higher cell density.

In conclusion, surface topography demonstrates the ability to modulate the behaviour of CECs such as morphology and proliferation. We demonstrate that topographical cues with the combination of surface chemical and physical properties such as ECM coatings and optimized substrate stiffness promotes better in vitro CE development. The bioinspired approach presented in this work for generation of in vivo like microenvironment is especially critical for $\mathrm{CE}$ development due to the significant need for alternative therapeutic methods. Our report establishes that dictating the hexagonal microtopography with an optimized cell-to-cell distance and designing the surface is an effective strategy for engineering CEC monolayers. We show that changing surface topography via bioinspiration approaches can enhance cell proliferation and cell-cell interactions by providing cells with equal areas to spread while retaining functional markers. This concept can be used for designing engineered CE monolayers using fewer cells and

This article is protected by copyright. All rights reserved. 
superior properties combined with further studies with more efficient topographical properties. Bioinspired patterned hydrogels and future concepts of engineered cell monolayers might be transferred in vitro ocular drug testing and clinical applications. These patterned hydrogels can also be incorporated into microfluidics-based organ-on-a-chip platforms.

\section{Acknowledgments}

This study was supported by Bogazici University Research Fund by Grant Numbers 11501 and 6701. FZEB would like to thank TUBITAK 2210-C Program of Domestic Graduate Scholarship in Priority Areas (2015/2) for their support. CE acknowledges the support from The Science Academy, Turkey through the Young Scientist Award Program.

\section{Authorship Contribution Statement}

FZEB conceptualized, designed, conducted experiments, and wrote the manuscript. AO designed, conducted experiments, and wrote the manuscript. MÖÖÖ conceptualized, helped interpret data and reviewed the manuscript. MM fabricated silicon wafer molds. CE oversaw microfabrication processes, helped interpret data and reviewed the manuscript. OB conducted mechanical analysis experiments. RR helped conceptualization, interpret data, and reviewed the manuscript. BG oversaw all the experiments, reviewed and edited the manuscript.

\section{Conflict of Interest Statement}

Authors declare no conflict of interest.

\section{REFERENCES}

Aratyn-Schaus, Y., Oakes, P. W., Stricker, J., Winter, S. P., \& Gardel, M. L. (2010). Preparation of complaint matrices for quantifying cellular contraction. Journal of Visualized Experiments : JoVE, (46), 1-6. https://doi.org/10.3791/2173

Bartakova, A., Kunzevitzky, N. J., \& Goldberg, J. L. (2014). Regenerative Cell Therapy for 
Corneal Endothelium. Current Ophthalmology Reports, 2(3), 81-90.

https://doi.org/10.1007/s40135-014-0043-7

Beningo, K. A., Lo, C. M., \& Wang, Y. L. (2002). Flexible polyacrylamide substrata for the analysis of mechanical interactions at cell-substratum adhesions. Methods in Cell Biology, Vol. 2002, pp. 325-339. https://doi.org/10.1016/S0091-679X(02)69021-1

Bettinger, C. J., Langer, R., \& Borenstein, J. T. (2009). Engineering Substrate Micro- and Nanotopography to Control Cell Function. Angewandte Chemie (International Ed. in English), 48(30), 5406-5415. https://doi.org/10.1002/anie.200805179

Bonanno, J. A. (2012). Molecular mechanisms underlying the corneal endothelial pump. Experimental Eye Research, 95(1), 2-7. https://doi.org/10.1016/j.exer.2011.06.004

Borderie, V. M., Scheer, S., Touzeau, O., Vedie, F., Carvajal-Gonzalez, S., \& Laroche, L. (1998). Donor organ cultured corneal tissue selection before penetrating keratoplasty. British Journal of Ophthalmology, 82(4), 382-388. https://doi.org/10.1136/bjo.82.4.382

Bourne, W. M. (2003). Biology of the corneal endothelium in health and disease. Eye (London, England), 17(8), 912-918. https://doi.org/10.1038/sj.eye.6700559

Chen, R., \& Hunt, J. A. (2007). Biomimetic materials processing for tissue-engineering processes. Journal of Materials Chemistry, 17(38), 3974-3979. https://doi.org/10.1039/b706765h

Choi, J. S., Williams, J. K., Greven, M., Walter, K. A., Laber, P. W., Khang, G., \& Soker, S. (2010). Bioengineering endothelialized neo-corneas using donor-derived corneal endothelial cells and decellularized corneal stroma. Biomaterials, 31(26), 6738-6745. https://doi.org/10.1016/j.biomaterials.2010.05.020

Derycke, L. D. M., \& Bracke, M. E. (2004). N-cadherin in the spotlight of cell-cell adhesion, differentiation, invasion and signalling. International Journal of Developmental Biology, Vol. 48, pp. 463-476. https://doi.org/10.1387/ijdb.0417931d

Discher, D. E., Janmey, P., \& Wang, Y.-L. (2005). Tissue cells feel and respond to the stiffness of their substrate. Science (New York, N.Y.), 310(5751), 1139-1143. https://doi.org/10.1126/science.1116995

This article is protected by copyright. All rights reserved. 
Eghrari, A. O., Riazuddin, S. A., \& Gottsch, J. D. (2015). Overview of the Cornea: Structure, Function, and Development. In Progress in Molecular Biology and Translational Science (1st ed., Vol. 134, pp. 7-23). https://doi.org/10.1016/bs.pmbts.2015.04.001

Engler, A. J., Sen, S., Sweeney, H. L., \& Discher, D. E. (2006). Matrix Elasticity Directs Stem Cell Lineage Specification. Cell, 126(4), 677-689. https://doi.org/10.1016/j.cell.2006.06.044

Erkoc, F. Z. (2017). Developing Artificial Corneal Endothelium Microenvironment Using Bioinspired Approach. MSc Thesis Bogaziçi University, Istanbul.

Gutermuth, A., Maassen, J., Harnisch, E., Kuhlen, D., Sauer-Budge, A., Skazik-Voogt, C., \& Engelmann, K. (2019). Descemet's Membrane Biomimetic Microtopography Differentiates Human Mesenchymal Stem Cells into Corneal Endothelial-Like Cells. Cornea, 38(1), 110 119. https://doi.org/10.1097/ICO.0000000000001765

Heras-Bautista, C. O., Katsen-Globa, A., Schloerer, N. E., Dieluweit, S., Abd El Aziz, O. M., Peinkofer, G., ... Pfannkuche, K. (2014). The influence of physiological matrix conditions on permanent culture of induced pluripotent stem cell-derived cardiomyocytes. Biomaterials, 35(26), 7374-7385. https://doi.org/10.1016/j.biomaterials.2014.05.027

Joyce, N. C. (2003). Proliferative capacity of the corneal endothelium. Progress in Retinal and Eye Research, Vol. 22, pp. 359-389. https://doi.org/10.1016/S1350-9462(02)00065-4

Joyce, N. C. (2012). Proliferative capacity of corneal endothelial cells. Experimental Eye Research, 95(1), 16-23. https://doi.org/10.1016/j.exer.2011.08.014

Kandow, C. E., Georges, P. C., Janmey, P. A., \& Beningo, K. A. (2007). Polyacrylamide Hydrogels for Cell Mechanics: Steps Toward Optimization and Alternative Uses. Methods in Cell Biology, 83(07), 29-46. https://doi.org/10.1016/S0091-679X(07)83002-0

Koo, S., Muhammad, R., Peh, G. S. L., Mehta, J. S., \& Yim, E. K. F. (2014). Micro- and nanotopography with extracellular matrix coating modulate human corneal endothelial cell behavior. Acta Biomaterialia, 10(5), 1975-1984. https://doi.org/10.1016/j.actbio.2014.01.015

Lai, J.-Y., Chen, K.-H., \& Hsiue, G.-H. (2007). Tissue-engineered human corneal endothelial cell sheet transplantation in a rabbit model using functional biomaterials. Transplantation,

This article is protected by copyright. All rights reserved. 
84(10), 1222-1232. https://doi.org/10.1097/01.tp.0000287336.09848.39

Lanniel, M., Huq, E., Allen, S., Buttery, L., Williams, P. M., \& Alexander, M. R. (2011). Substrate induced differentiation of human mesenchymal stem cells on hydrogels with modified surface chemistry and controlled modulus. Soft Matter, 7(14), 6501-6514. https://doi.org/10.1039/c1sm05167a

Last, J. A., Liliensiek, S. J., Nealey, P. F., \& Murphy, C. J. (2009). Determining the mechanical properties of human corneal basement membranes with atomic force microscopy. Journal of Structural Biology, 167(1), 19-24. https://doi.org/10.1016/j.jsb.2009.03.012

Molladavoodi, S., Kwon, H.-J., Medley, J., \& Gorbet, M. (2015). Human corneal epithelial cell response to substrate stiffness. Acta Biomaterialia, 11, 324-332. https://doi.org/10.1016/j.actbio.2014.10.005

Palchesko, R. N., Lathrop, K. L., Funderburgh, J. L., \& Feinberg, A. W. (2015). In Vitro Expansion of Corneal Endothelial Cells on Biomimetic Substrates. Scientific Reports, 5(1), 7955. https://doi.org/10.1038/srep07955

Peh, G. S. L., Toh, K. P., Ang, H. P., Seah, X. Y., George, B. L., \& Mehta, J. S. (2013). Optimization of human corneal endothelial cell culture: Density dependency of successful cultures in vitro. BMC Research Notes, 6(1), 176. https://doi.org/10.1186/1756-0500-6-176

Rizwan, M., Peh, G. S., Adnan, K., Naso, S. L., Mendez, A. R., Mehta, J. S., \& Yim, E. K. F. (2016). In Vitro Topographical Model of Fuchs Dystrophy for Evaluation of Corneal Endothelial Cell Monolayer Formation. Advanced Healthcare Materials, 5(22), 2896-2910. https://doi.org/10.1002/adhm.201600848

Rizwan, M., Peh, G. S. L., Ang, H. P., Lwin, N. C., Adnan, K., Mehta, J. S., .. Yim, E. K. F. (2017). Sequentially-crosslinked bioactive hydrogels as nano-patterned substrates with customizable stiffness and degradation for corneal tissue engineering applications. Biomaterials, 120, 139-154. https://doi.org/10.1016/j.biomaterials.2016.12.026

Shin, H., Jo, S., \& Mikos, A. G. (2003). Biomimetic materials for tissue engineering. Biomaterials, 24(24), 4353-4364. https://doi.org/10.1016/S0142-9612(03)00339-9

Stanton, A. E., Tong, X., \& Yang, F. (2019). Extracellular matrix type modulates

This article is protected by copyright. All rights reserved. 
mechanotransduction of stem cells. Acta Biomaterialia, 96, 310-320.

https://doi.org/10.1016/j.actbio.2019.06.048

Tan, D. T. H. H., Dart, J. K. G. K. G., Holland, E. J., \& Kinoshita, S. (2012). Corneal transplantation. The Lancet, 379(9827), 1749-1761. https://doi.org/10.1016/S01406736(12)60437-1

Teo, B. K. K., Goh, K. J., Ng, Z. J., Koo, S., \& Yim, E. K. F. (2012). Functional reconstruction of corneal endothelium using nanotopography for tissue-engineering applications. Acta Biomaterialia, 8(8), 2941-2952. https://doi.org/10.1016/j.actbio.2012.04.020

Theocharis, A. D., Skandalis, S. S., Gialeli, C., \& Karamanos, N. K. (2016). Extracellular matrix structure. Advanced Drug Delivery Reviews, Vol. 97, pp. 4-27. https://doi.org/10.1016/j.addr.2015.11.001

Vassilev, V. S., Mandai, M., Yonemura, S., \& Takeichi, M. (2012). Loss of N-Cadherin from the endothelium causes stromal edema and epithelial dysgenesis in the mouse cornea. Investigative Ophthalmology and Visual Science, 53(11), 7183-7193. https://doi.org/10.1167/iovs.12-9949

Wang, L., \& L., R. (2011). Biomimetic Topography: Bioinspired Cell Culture Substrates and Scaffolds. In Advances in Biomimetics (pp. 453-472). https://doi.org/10.5772/14383

Xia, Y., \& Whitesides, G. M. (1998). Soft lithography. Annual Review of Materials Science, 28(1), 153-184. https://doi.org/10.1146/annurev.matsci.28.1.153

Xiong, S., Gao, H. C., Qin, L., Jia, Y. G., \& Ren, L. (2019). Engineering topography: Effects on corneal cell behavior and integration into corneal tissue engineering. Bioactive Materials, Vol. 4, pp. 293-302. https://doi.org/10.1016/j.bioactmat.2019.10.001

Zavala, J., Ló Pez Jaime, G., Barrientos, C. R., \& Valdez-Garcia, J. (2013). Corneal endothelium: developmental strategies for regeneration. Eye, 27(January), 579-588. https://doi.org/10.1038/eye.2013.15

\section{Figure Legends}

This article is protected by copyright. All rights reserved. 
Figure 1. A) PA gels polymerized on non-patterned flat, small patterned and large patterned molds as captured with bright field microscopy. Scale bar, $50 \mu \mathrm{m}, \mathrm{B})$ Stress-strain curve obtained from PA hydrogels with Dynamic Mechanical Analysis measurement. C) Water contact angle measurement results and sample photographs obtained from uncoated and Col IV coated PA surfaces, data were given as means $\pm \mathrm{SD}, \mathrm{p}<0.0001$, D-E) Sample fluorescence micrographs (Scale bar, $200 \mu \mathrm{m}$ ) and fluorescence intensities obtained from PA hydrogels after immunostaining for Col IV, $\mathrm{p}<0.0001$.

Figure 2. Sample bright field microscopy images of BCECs 7 days after seeding on uncoated and Col IV coated PA hydrogels with different patterns. Scale bar, $200 \mu \mathrm{m}$.

Figure 3. The results of MTT assay for BCECs 1 and 7 days after seeding on PA hydrogels with different patterns. Cell viability on small patterned hydrogels was significantly higher vs. flat $(* \mathrm{p}<0.05)$ and large patterned hydrogels $(* * * \mathrm{p}<0.001)$.

Figure 4. Fluorescence microscopy images of BCECs stained with phalloidin for F-actin 7 days after seeding on TCP, flat PA hydrogels, PA hydrogels with small and large patterns. All hydrogels were coated with Col IV. Scale bar, $200 \mu \mathrm{m}$.

Figure 5. A) Fluorescence microscopy images of BCECs immunostained for $\mathrm{Na}^{+} / \mathrm{K}^{+}$ATPase 7 days after seeding on PA hydrogels with different patterns. Scale bar, $100 \mu \mathrm{m}, \mathrm{B}$ ) Total $\mathrm{Na}^{+} / \mathrm{K}^{+}$ ATPase levels of these groups as probed by Western Blot assays and sample bands, C) Cell densities of these groups as calculated from these images. Small patterned substrates were significantly more densely populated compared to other PA substrates $(* * * * \mathrm{p}<0.0001$ vs. large patterned and $* * * \mathrm{p}<0.001$ vs. flat substrate).

Figure 6. A) Fluorescence microscopy images of BCECs immunostained for N-cadherin 21 days after seeding on PA hydrogels with different patterns. Scale bar, $200 \mu \mathrm{m}$, B) Cell densities of these groups as calculated from these images. Small patterned substrates were significantly $(* * \mathrm{p}=0.001$ vs. flat and $* * * * \mathrm{p}<0.0001$ vs. large patterned substrates) more densely populated compared to other PA substrates.

This article is protected by copyright. All rights reserved. 

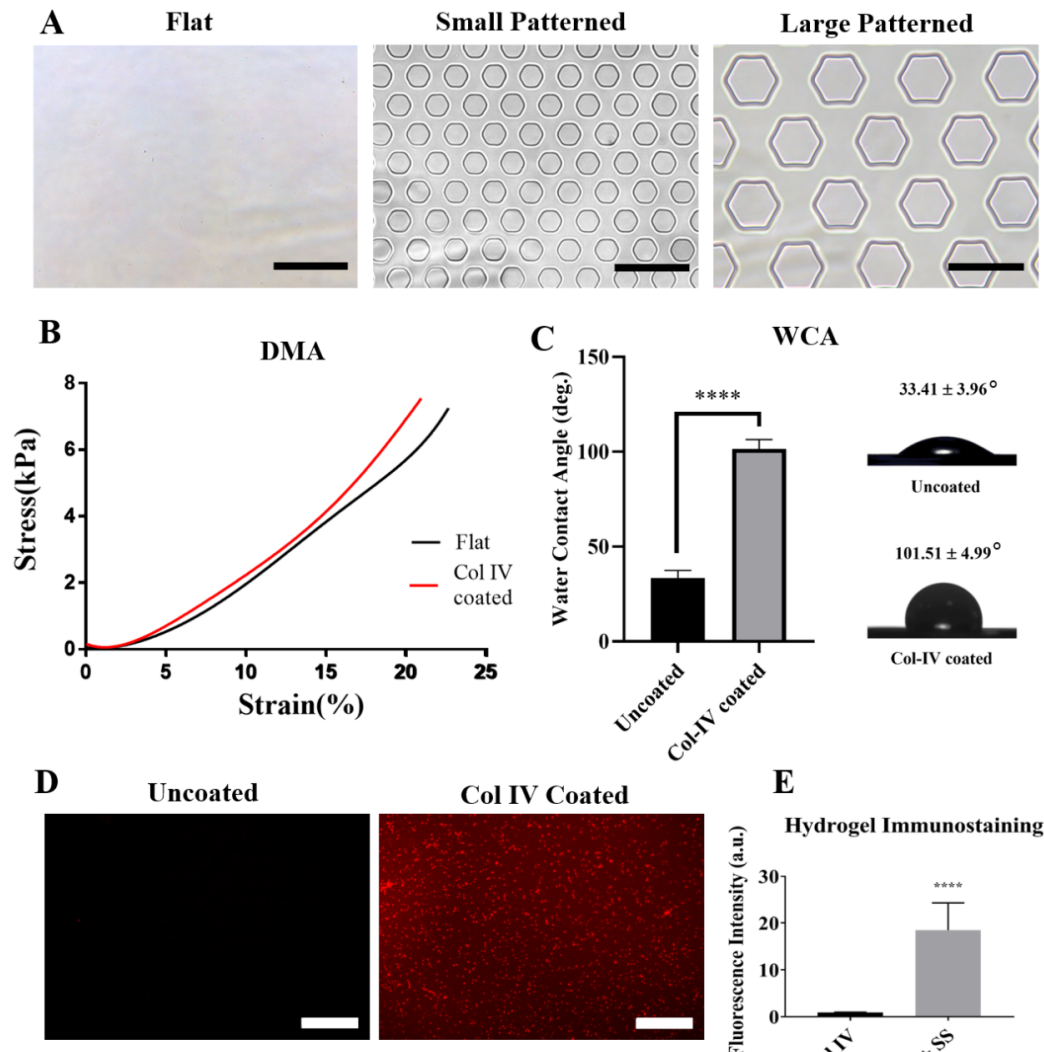

E

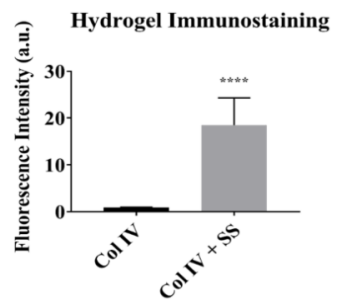

This article is protected by copyright. All rights reserved. 
Flat
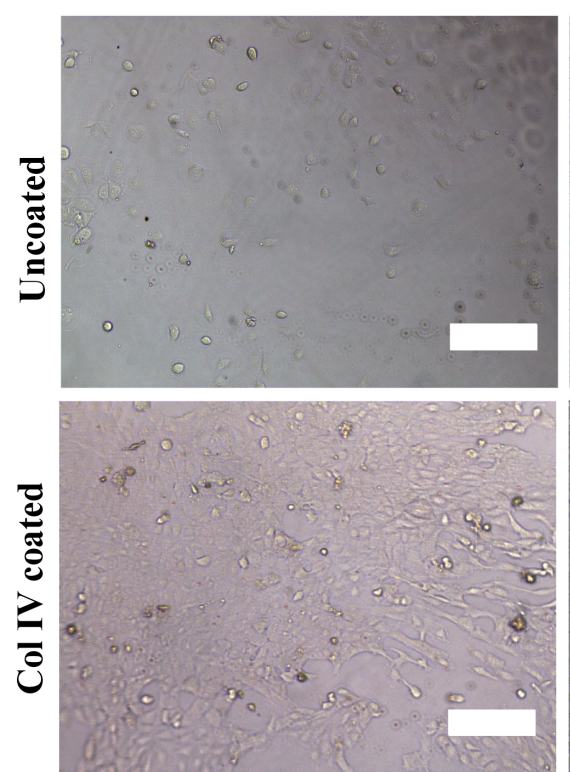

Small Patterned
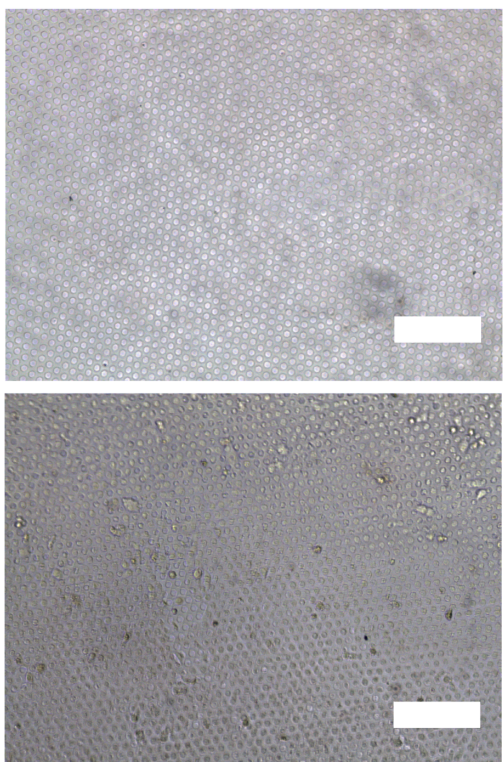

Large Patterned
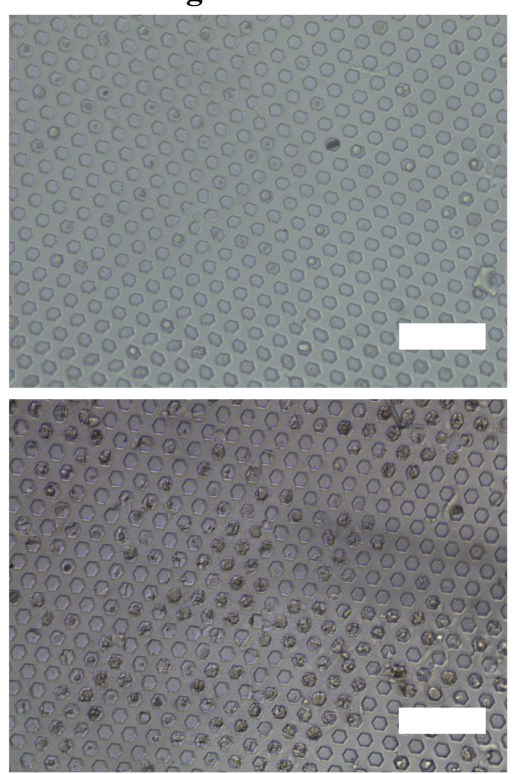

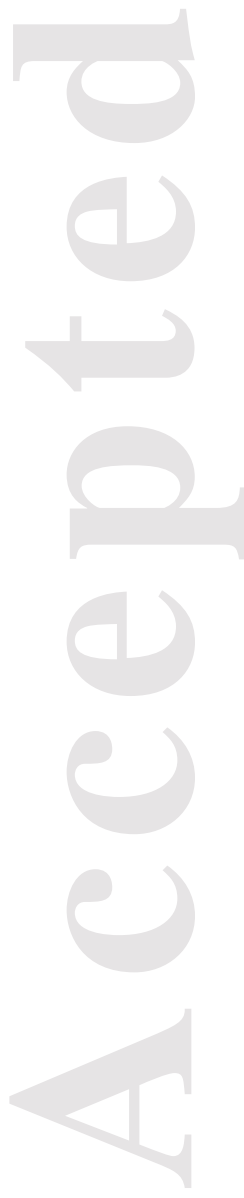

This article is protected by copyright. All rights reserved. 


\section{MTT Assay}

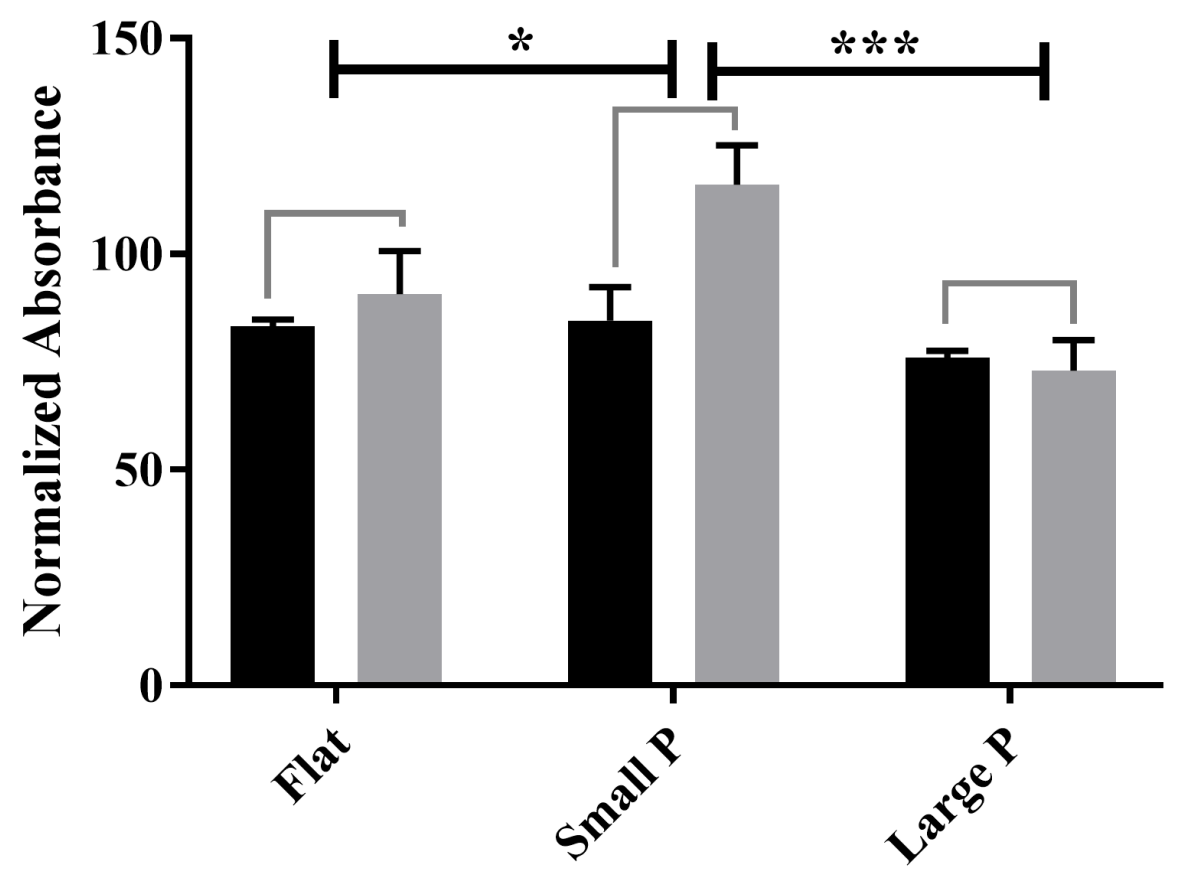

Day 1

Day 7 

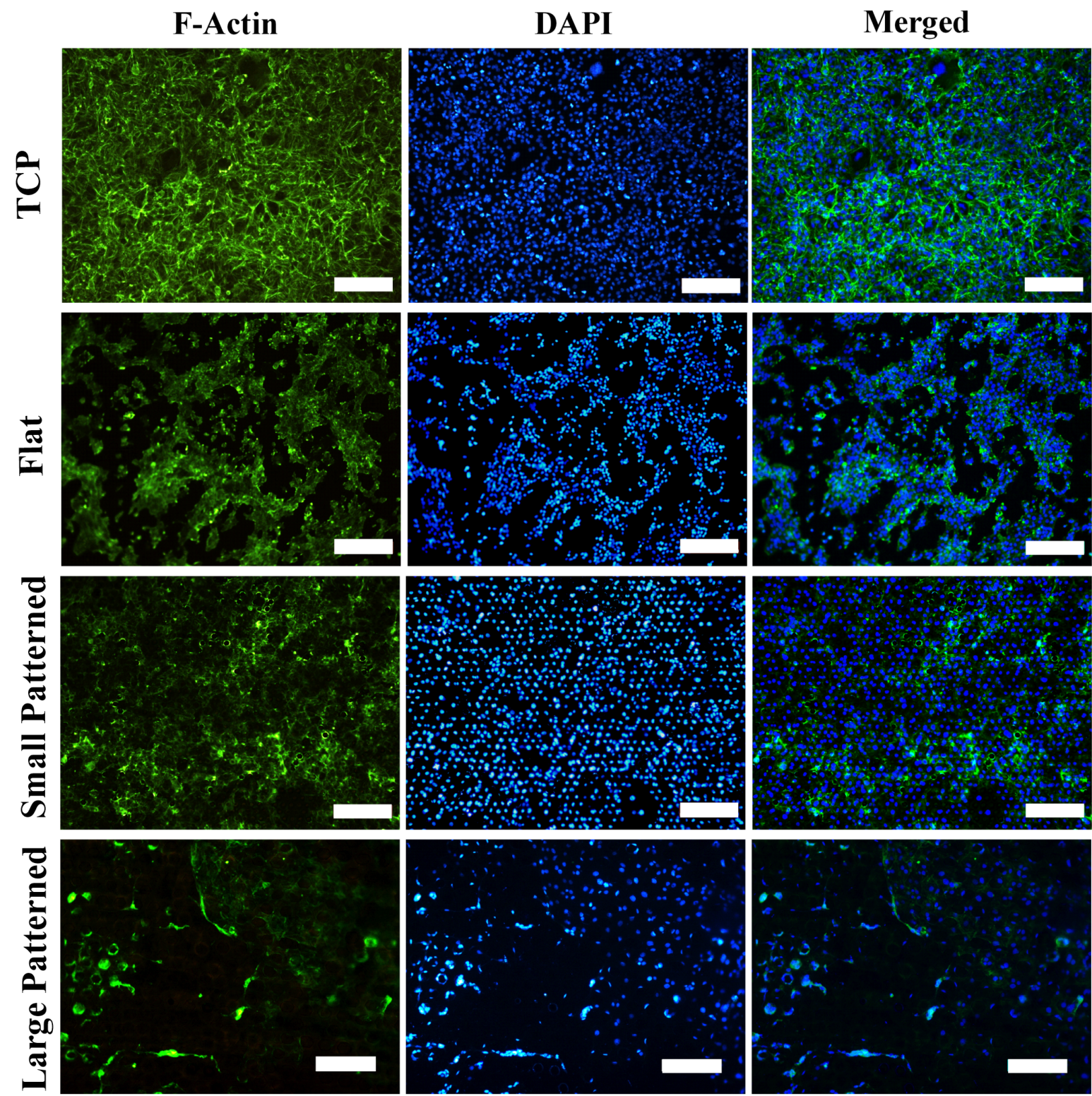

This article is protected by copyright. All rights reserved. 
A
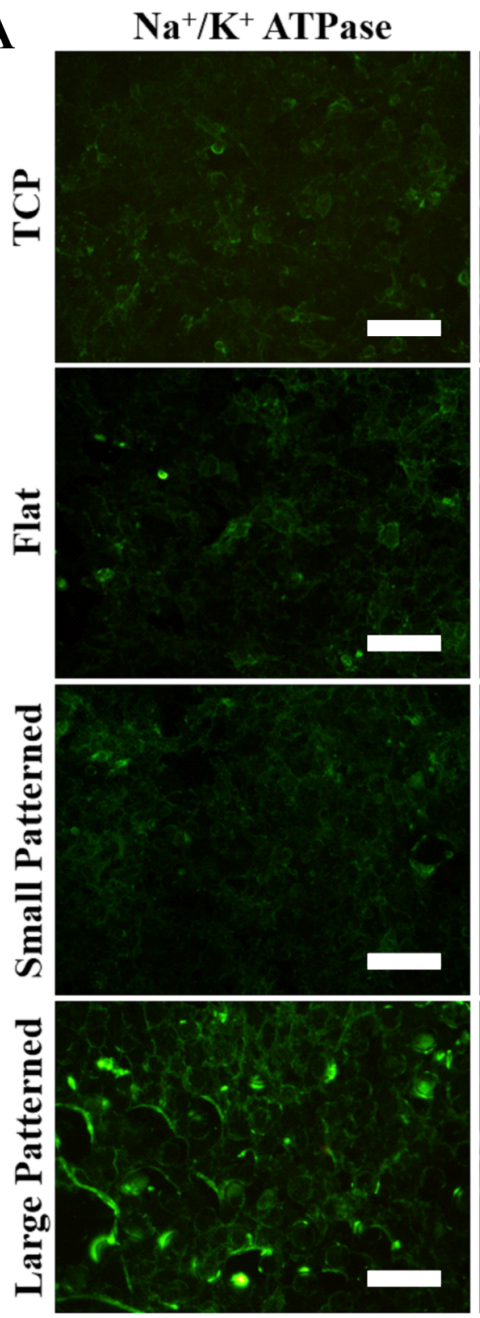

B
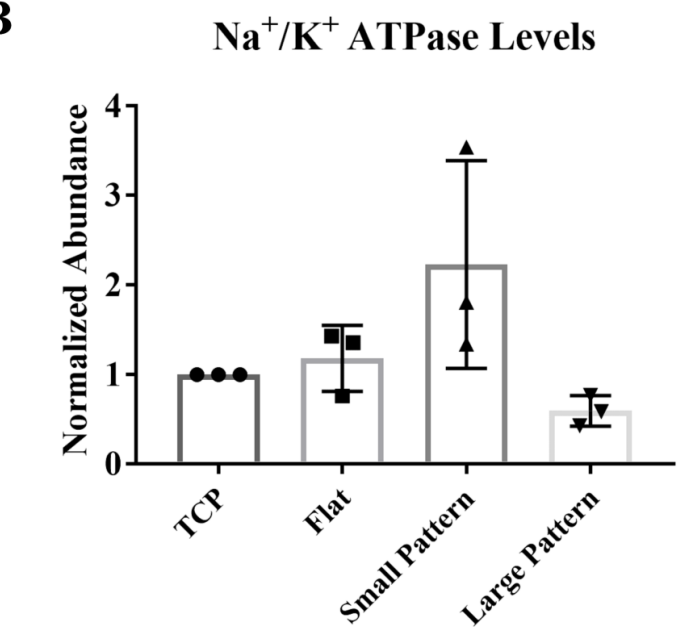

DAPI
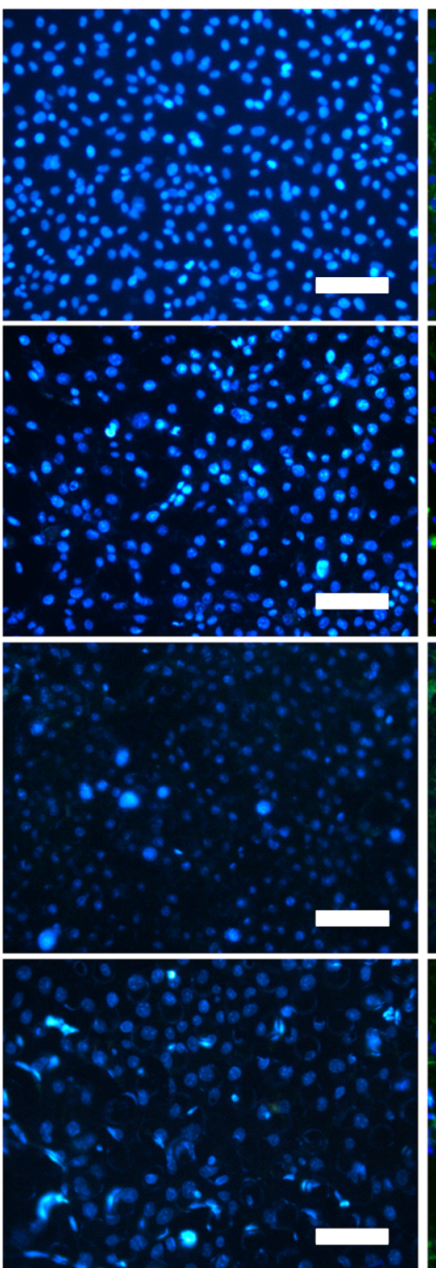

C

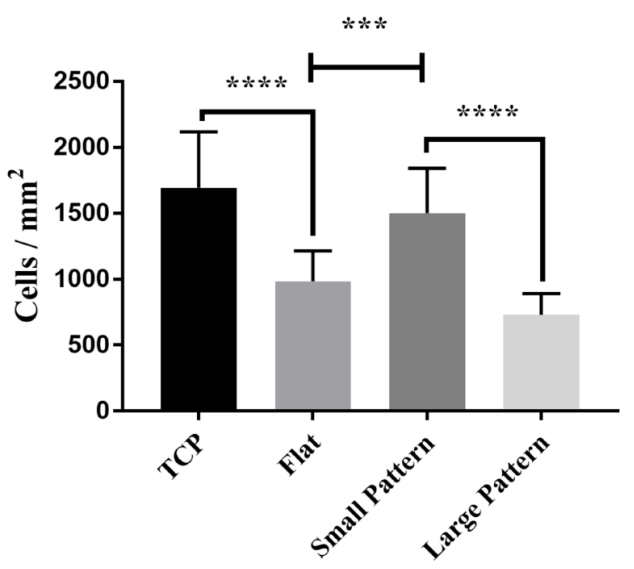

$\mathrm{Na}^{+} / \mathrm{K}^{+}$ATPase

$\beta$-actin

This article is protected by copyright. All rights reserved. 


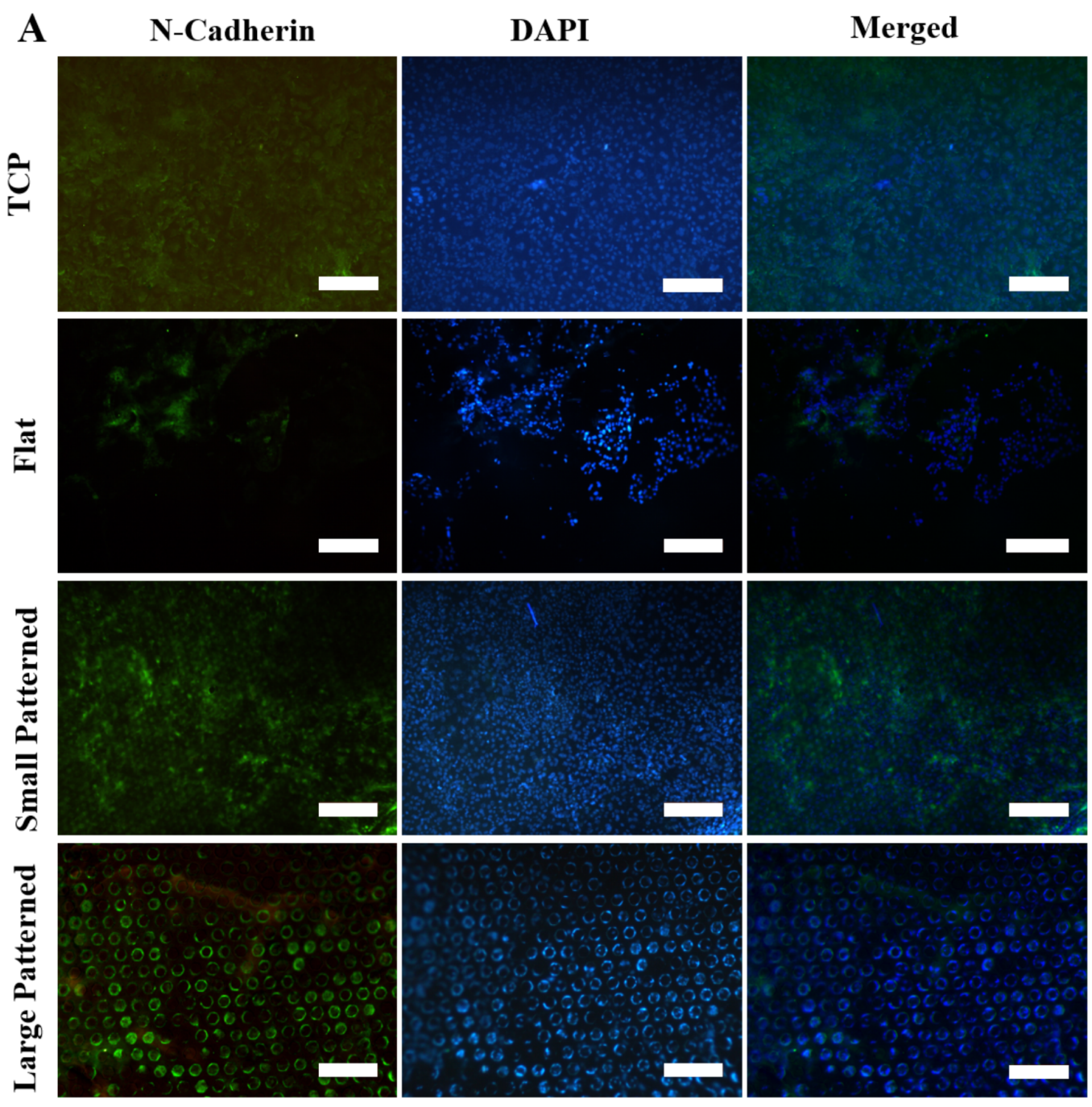

B

Cell Densities

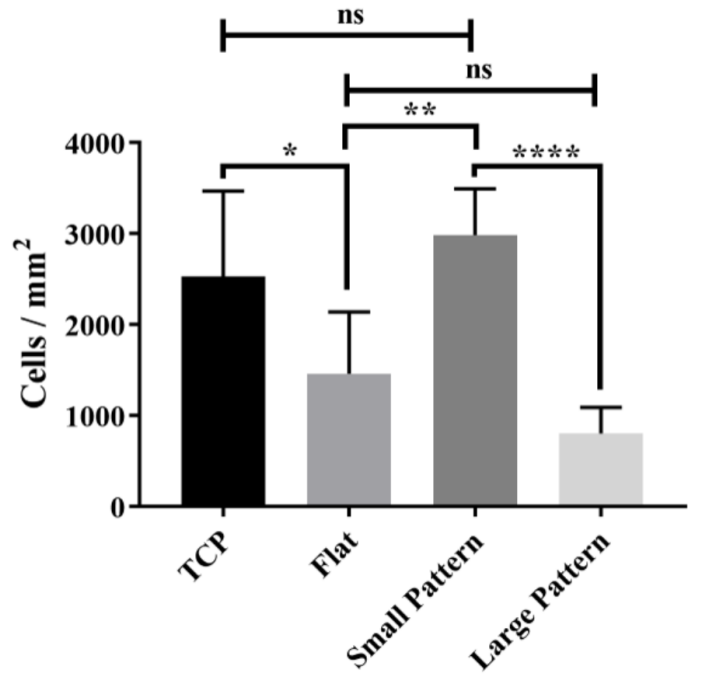

This article is protected by copyright. All rights reserved. 